\title{
Alina Grynia
}

Uniwersytet w Białymstoku; Wydział Ekonomiczno-Informatyczny w Wilnie e-mail: grynia@uwb.edu.pl

\section{ZMIANY NA RYNKACH PRACY KRAJÓW EUROPY ŚRODKOWO-WSCHODNIEJ W KONTEKŚCIE ICH KONKURENCYJNOŚCI MIĘDZYNARODOWEJ}

\section{CHANGES ON THE LABOR MARKETS IN CEE COUNTRIES IN THE CONTEXT OF THEIR INTERNATIONAL COMPETITIVENESS}

DOI: $10.15611 /$ pn.2018.529.09

JEL Classification: E24, J1, J16

Streszczenie: Wzrost aktywności gospodarczej w krajach EŚW skutkuje wzrostem popytu na pracę. Jednakże rosnącemu popytowi nie towarzyszy rosnąca podaż pracy. Wręcz odwrotnie, w ostatnich latach uwidacznia się problem kurczenia się podaży pracy. Kurcząca się podaż pracy w krajach EŚW może stanowić istotną barierę wzrostu i skutkować pogorszeniem ich konkurencyjności międzynarodowej. Celem artykułu jest określenie głównych trendów na rynku pracy w krajach Europy Środkowo-Wschodniej w latach 2007-2017 w kontekście kształtowania ich zdolności konkurencyjnej. Oceny sytuacji na krajowych rynkach pracy dokonano na podstawie analizy wybranych wskaźników: zatrudnienia, bezrobocia, salda migracji, mediany wieku oraz obciążenia demograficznego. Określenia zaś roli rynku pracy w kształtowaniu konkurencyjności krajów EŚW dokonano w oparciu o raporty Światowego Forum Ekonomicznego.

Słowa kluczowe: rynek pracy, konkurencyjność gospodarki, kraje Europy Środkowo-Wschodniej.

Summary: The increase in economic activity in the CEE countries leads to an increase in labor demand. However, growing demand for labor is not responding to growing supply. In recent years, the problem of decreasing labor supply has become apparent. Declining labor supply in the CEE countries may become a significant barrier to growth and lead to the deterioration of their international competitiveness. The aim of the article is to determine the main trends on the labor market in the countries of Central and Eastern Europe in 2007-2017 in the context of their competitive ability. The situation on the national labor markets was assessed based on an analysis of selected indicators: employment, unemployment, migration balance, median age and demographic burden. The determination of the role of the labor market in shaping the competitiveness of CEE countries was made on the basis of the reports of the World Economic Forum.

Keywords: labor market, competitiveness of the economy, CEE countries. 


\section{Wstęp}

Zdolność konkurencyjna gospodarki narodowej jest oceniana na podstawie wielu czynników, które opisują wielkość, strukturę i wykorzystanie zasobów produkcyjnych, a także politykę rządu oraz międzynarodowe otoczenie gospodarcze. Światowe Forum Ekonomiczne używa szerokiego zestawu takich czynników, połączonych w 12 ,filarach konkurencyjności”. Jeden z takich filarów ocenia efektywność funkcjonowania krajowego rynku pracy.

Funkcjonowanie rynku pracy determinuje wiele czynników o charakterze ekonomicznym, społecznym i politycznym. Czynniki te mogą zarówno usprawniać jego funkcjonowanie, jak i zakłócać. Kluczowymi determinantami zmian na rynkach pracy krajów Europy Środkowo-Wschodniej (EŚW) są procesy integracyjne, gwarantujące wolny przepływ siły roboczej, oraz zmniejszające się zasoby pracy. Sytuacja na rynkach pracy jest powiązana z sytuacją gospodarczą panującą w poszczególnych krajach członkowskich UE. Przezwyciężenie recesji gospodarczej spowodowanej kryzysem i powrót na ścieżkę wzrostu skutkowało poprawę tej sytuacji, co znalazło odzwierciedlenie w rosnącym zatrudnieniu i spadającym poziomie bezrobocia. Niemniej jednak rosnący popyt na pracę w coraz mniejszym stopniu jest zaspokajany przez krajowe zasoby pracy. Kurczenie się podaży pracy może stanowić istotną barierę wzrostu gospodarczego w tych krajach oraz obniżyć ich zdolność konkurencyjną.

Celem artykułu jest ocena zmian zachodzących na rynkach pracy w krajach Europy Środkowo-Wschodniej w kontekście ich zdolności konkurencyjnej. W pierwszej kolejności na podstawie analizy wybranych wskaźników dokonano oceny sytuacji na rynkach pracy krajów EŚW. Następnie podjęto próbę określenia roli rynku pracy w kształtowaniu konkurencyjności krajów EŚW. Okres badawczy zawężono do lat 2007-2017, głównie z powodu zmian w metodologii stosowanej przez Światowe Forum Ekonomiczne (WEF). Dane zaczerpnięto z bazy Eurostat, ONZ i raportów WEF. Metodą badawczą jest analiza wskaźnikowa i przyczynowo-skutkowa.

\section{Zmiany na rynkach pracy w krajach EŚW w świetle wybranych wskaźników}

Ogólnie można uznać, iż rynek pracy krajów EŚW w analizowanym okresie rozwijał się relatywnie dobrze. Oczywiście wyjątek stanowią lata recesji gospodarczej (2008-2010), która charakteryzowała się dotkliwym spadkiem produkcji i wzrostem bezrobocia. Pod względem głębokości recesji analizowane kraje znacząco się różniły. Jedynym krajem, który odnotował tylko spowolnienie gospodarcze, była Polska. Tymczasem w przypadku krajów bałtyckich można mówić o depresji gospodarczej: spadek PKB w 2009 r. w relacji do roku poprzedniego o 14-15\% oraz wzrost bezrobocia do poziomu 13-17\% [Eurostat 2017]. Pozostałe kraje w różnym stopniu odczuły skutki spadku ogólnej aktywności gospodarczej. 
Rynki pracy krajów EŚW charakteryzowały się zróżnicowanymi procesami dostosowawczymi do negatywnego szoku ekonomicznego. O skuteczności zastosowanych narzędzi świadczy poprawa wskaźników zatrudnienia i bezrobocia w latach 2010-2017 we wszystkich analizowanych krajach (tab. 1). Poziom zatrudnienia najbardziej wzrósł w tych krajach, które doświadczyły największego jego spadku w poprzednich latach, przede wszystkim w krajach bałtyckich, ale także na Węgrzech. Warto odnotować, iż nawet w krajach bałtyckich spadek zatrudnienia okazał się znacznie mniejszy, niż można było tego spodziewać się po głębokości recesji.

Tabela 1. Zmiany w zakresie zatrudnienia i bezrobocia w krajach EŚW w latach 2007-2017

\begin{tabular}{|c|c|c|c|c|c|c|c|c|c|c|}
\hline \multirow{3}{*}{ Kraj } & 2007 & 2010 & $2007-2010$ & 2017 & 2010-2017 & 2007 & 2010 & $2007-2010$ & 2017 & $2010-2017$ \\
\hline & \multicolumn{5}{|c|}{ stopa zatrudnienia } & \multicolumn{5}{|c|}{ stopa bezrobocia } \\
\hline & $\%$ & $\%$ & p.p. & $\%$ & $\%$ & $\%$ & $\%$ & p.p. & $\%$ & $\%$ \\
\hline BG & 61,7 & 59,8 & $-1,9$ & 66,9 & 7,1 & 6,9 & 10,3 & 3,4 & 6,2 & $-4,1$ \\
\hline $\mathrm{CZ}$ & 66,1 & 65,0 & $-1,1$ & 73,6 & 8,6 & 5,3 & 7,3 & 2 & 2,9 & $-4,4$ \\
\hline $\mathrm{EE}$ & 69,8 & 61,2 & $-8,6$ & 74,1 & 12,9 & 4,6 & 16,7 & 12,1 & 5,8 & $-10,9$ \\
\hline LV & 68,1 & 58,5 & $-9,6$ & 70,1 & 11,6 & 6,1 & 19,5 & 13,4 & 8,7 & $-10,8$ \\
\hline LT & 65,0 & 57,6 & $-7,4$ & 70,4 & 12,8 & 4,3 & 17,8 & 13,5 & 7,1 & $-10,7$ \\
\hline $\mathrm{HU}$ & 57,0 & 54,9 & $-2,1$ & 68,2 & 13,3 & 7,4 & 11,2 & 3,8 & 4,2 & -7 \\
\hline PL & 57,0 & 58,9 & 1,9 & 66,1 & 7,2 & 9,6 & 9,7 & 0,1 & 4,9 & $-4,8$ \\
\hline $\mathrm{RO}$ & 58,8 & 60,2 & 1,4 & 63,9 & 3,7 & 6,4 & 7 & 0,6 & 4,9 & $-2,1$ \\
\hline SI & 67,8 & 66,2 & $-1,6$ & 69,3 & 3,1 & 4,9 & 7,3 & 2,4 & 6,6 & $-0,7$ \\
\hline SK & 60,7 & 58,8 & $-1,9$ & 66,2 & 7,4 & 11,2 & 14,5 & 3,3 & 8,1 & $-6,4$ \\
\hline
\end{tabular}

Źródło: [Eurostat 2017].

Najwyższa stopa zatrudnienia w 2017 r. odnotowana w Estonii i Czechach to ok. $74 \%$. W tych krajach stopa zatrudnienia jest zbliżona do sytuacji w krajach skandynawskich, które uznaje się za wzór do naśladowania, pracuje tam bowiem ok. 75\% osób w wieku produkcyjnym. Pozostałe dwa kraje bałtyckie - Litwa i Łotwa - także legitymują się relatywnie wysokim wskaźnikiem na poziomie $70 \%$. Najniższy poziom zatrudnienia odnotowano w Rumunii - ok. 64\%. Porównanie do średniego poziomu w UE-28 pokazuje, iż 4 kraje z tej grupy mają niższe wyniki: Bułgaria, Rumunia, Słowacja i Polska. Odnotować jednak należy, iż wszystkie kraje EŚW osiągnęły poziom sprzed kryzysu, a nawet znacznie zwiększyły zatrudnienie.

Obserwacja zmian na rynkach pracy krajów EŚW w zakresie poziomu bezrobocia prowadzi do podobnych wniosków. W latach 2010-2017 poziom bezrobocia obniżył się we wszystkich analizowanych krajach. W 2017 r. najniższą stopę bezrobocia odnotowano w Czechach - ok. 3\% oraz Polsce, Rumunii i na Węgrzech nieprzekraczającą 5\%. Tymczasem poziom bezrobocia wyższy od średniej unijnej utrzymuje się na Łotwie i w Słowacji - odpowiednio 8,7 i 8,1\%. Warto dodać, iż 
cztery kraje EŚW w 2017 r. notowały wyższe bezrobocie aniżeli przed kryzysem. Są to kraje bałtyckie oraz Słowenia.

Rosnące zatrudnienie i spadające bezrobocie można uznać za pozytywne zmiany na rynkach pracy $\mathrm{w}$ tym regionie. Zachodzące zmiany są mocno powiązane $\mathrm{z}$ sytuacją gospodarczą, panującą w poszczególnych krajach EŚW i Europy Zachodniej. Dynamika wzrostu PKB w krajach EŚW jest relatywnie wyższa niż w całym ugrupowaniu. W 2017 r. wskaźnik ten dla UE-28 kształtował się na poziomie 2,5\%, natomiast dla krajów EŚW był o 2 p.p. wyższy. Wzrost aktywności gospodarczej skutkuje poprawą sytuacji na rynkach pracy głównie z powodu rosnącego popytu na pracę wśród przedsiębiorstw prywatnych. Jednakże rosnącemu popytowi na pracę nie towarzyszy rosnąca podaż pracy. Wręcz odwrotnie, w ostatnich latach uwidacznia się problem kurczenia się podaży pracy, starzenia się zasobów pracy oraz wzrost obciążenia demograficznego ludnością $\mathrm{w}$ wieku poprodukcyjnym.

W 2007 r. w dziesięciu badanych krajach mieszkało blisko 101,3 mln osób, z czego blisko 70\% stanowili mieszkańcy trzech krajów: 39\% - Polski, 20\% - Rumunii i $11 \%$ - Czech. W ciągu dziesięciolecia liczba mieszkańców w tym regionie zmalała o 2,6 mln osób, czyli 2,6\% populacji. Ponad połowa ubytku (56\%) w regionie wynika ze spadku ludności w Rumunii. Znaczący spadek ludności miał miejsce także w Bułgarii (ok. 18\%), na Litwie (15\%) oraz w Czechach (12\%). Prognozy ONZ w zakresie ubytku ludności w latach 2015-2050 są bardzo niepokojące, liczba Europejczyków zmaleje o $24 \mathrm{mln}$ osób, a region EŚW utraci $11 \mathrm{mln}$ osób. Wewnątrz tego regionu świata tendencje spadkowe utrzymają się we wszystkich krajach, ale ich intensywność będzie różna. Największego ubytku doświadczą Polska i Rumunia - ponad 3,5 mln osób każda, Bułgaria - 1,6 mln i Litwa - blisko $1 \mathrm{mln}$ [UN 2017].

Spadek liczby ludności w krajach EŚW wynika głównie z dwóch powodów: spadku dzietności oraz intensywnych ruchów migracyjnych. Współczynnik dzietności (liczba urodzonych dzieci przypadających na jedną kobietę w wieku rozrodczym) w 2016 r. nie osiągnął granicy zastępowalności pokoleń $(2,10-2,15)$ dla żadnego z krajów EŚW. Jego wartość kształtowała się między 1,74 dla Łotwy i 1,39 dla Polski [Eurostat 2017].

Kształtowanie się salda migracji (przyrost/ubytek ludności danego kraju na skutek migracji przypadający na 1000 mieszkańców) w trzech okresach czasowych przedstawia tab. 2. Relatywnie dobrymi wynikami w tym zakresie (dodatnim saldem) wyróżniają się trzy kraje - Czechy, Słowenia i Węgry, tymczasem pozostałe notują ujemne wartości salda. Bardzo niekorzystnie na tle regionu wygląda sytuacja Łotwy, Litwy i Rumunii.

Wspomnianym procesom towarzyszy proces starzenia się ludności oraz zmiany proporcji między liczbą osób w wieku produkcyjnym i nieprodukcyjnym. Przeciętna wartość mediany wieku ludności w 2015 r. dla regionu EŚW oscylowała wokół wartości 41,7 roku i była znacznie wyższa niż na świecie. ONZ szacuje, iż w kolejnych latach proces starzenia się ludności będzie postępował. W 2025 r. najwyższa wartość wskaźnika (ok. 46 lat) wystąpi w Bułgarii i Słowenii. Konsekwencją odno- 
Tabela 2. Mediana wieku ludności (lata), saldo migracji oraz wskaźnik obciążenia demograficznego w wybranych latach (osoby)

\begin{tabular}{|l|r|r|l|l|l|l|r|r|r|r|}
\hline \multirow{2}{*}{ Kraj } & 2005 & 2015 & 2025 & 2005 & 2015 & 2025 & $2005-2010$ & $2010-2015$ & $2015-2020$ \\
\cline { 2 - 11 } & \multicolumn{3}{|c|}{ mediana wieku } & \multicolumn{2}{|c|}{ obciążenie demograficzne } & \multicolumn{3}{|c|}{ saldo migracji } \\
\hline BG & 41,2 & 43,5 & 46,0 & 25,1 & 30,5 & 35,9 & $-2,2$ & $-0,7$ & $-0,7$ \\
\hline CZ & 38,7 & 41,4 & 45,3 & 19,7 & 26,9 & 34,0 & 4,8 & 1,1 & 1,1 \\
\hline EE & 39,4 & 41,6 & 43,9 & 24,6 & 28,9 & 35,4 & $-2,3$ & $-1,6$ & $-0,8$ \\
\hline LV & 39,5 & 42,5 & 44,9 & 24,6 & 29,4 & 35,5 & $-7,9$ & $-8,1$ & $-5,1$ \\
\hline LT & 38,5 & 42,7 & 43,7 & 23,8 & 28,0 & 33,9 & $-9,3$ & $-9,7$ & $-1,7$ \\
\hline HU & 39,1 & 41,7 & 45,1 & 22,7 & 25,7 & 33,7 & 0,5 & 0,6 & 0,6 \\
\hline PL & 36,6 & 39,7 & 43,9 & 18,6 & 22,5 & 33,4 & $-0,9$ & $-0,4$ & $-0,3$ \\
\hline RO & 37.0 & 41,3 & 44,5 & 22,1 & 25,2 & 32,3 & $-7,4$ & $-3,0$ & $-1,5$ \\
\hline SI & 40,0 & 43,0 & 46,3 & 22,0 & 26,8 & 37,7 & 3,9 & 1,6 & 0,6 \\
\hline SK & 35,4 & 39,2 & 43,2 & 16,3 & 19,9 & 29,0 & $-0,3$ & 0,4 & 0,2 \\
\hline
\end{tabular}

Źródło: [UN 2017].

towanych zmian będzie wzrost wskaźnika obciążenia demograficznego. W $2025 \mathrm{r}$. na 100 mieszkańców Słowenii i Bułgarii w wieku produkcyjnym będzie przypadło odpowiednio 37,7 i 35,9 osoby w wieku emerytalnym.

Reasumując, znaczny ubytek ludności oraz zjawisko starzenia się populacji w kolejnych latach może istotnie zakłócić efektywne funkcjonowanie rynku pracy.

\section{Efektywność rynku pracy determinantą konkurencyjności międzynarodowej}

\subsection{Znaczenie rynku pracy w badaniach Światowego Forum Ekonomicznego}

Należy odnotować, iż istnieje duża liczba definicji pojęcia konkurencyjności międzynarodowej. Ogólnie rzecz ujmując, można przyjąć, iż konkurencyjność oznacza ,umiejętność konkurowania, a więc działania i przetrwania w konkurencyjnym otoczeniu” [Gorynia, Łaźniewska (red.) 2009, s. 50], inaczej mówiąc, „zdolność do skutecznego przeciwstawienia się konkurencji” [Burnewicz (red.) 1993, s. 23]. Takie ujęcie konkurencyjności można odnieść zarówno do przedsiębiorstw, jak i gospodarek narodowych. Wielu badaczy uważa, iż konkurencyjność międzynarodowa jest koncepcją wielowymiarową i należy ją analizować na różnych poziomach agregacji poprzez porównanie do innych krajów [Czajkowski, Gomułka 2010, s. 38; Gorynia, Jankowska 2008, s. 55-56]. Do oceny pozycji konkurencyjnej na szczeblu gospodarki narodowej najczęściej wykorzystuje się wskaźniki ilościowe pozwalające ocenić konkurencyjność danej gospodarki względem krajów odniesienia. 
Jedną z najczęściej przywoływanych definicji makrokonkurencyjności jest definicja proponowana przez Światowe Forum Ekonomiczne (World Economic Forum - WEF). WEF definiuje konkurencyjność jako zespolenie instytucji, polityki i czynników, które determinują poziom produktywności danego kraju. Zdaniem autorów raportu The Global Competitiveness Report 2016-2017 wysoki poziom produktywności pozwala osiągnąć wysokie dochody i wysoki poziom życia obywateli danego kraju, a co za tym idzie - wysoki poziom konkurencyjności [World Economic Forum 2016, s. 4].

W literaturze przedmiotu wyróżnia się dwa podejścia w postrzeganiu konkurencyjności międzynarodowej: statyczne i dynamiczne. Konkurencyjność w sensie statycznym jest zestawem cech gospodarki, które opisują jego pozycję konkurencyjną. Tymczasem konkurencyjność w sensie dynamicznym jest zestawem rezultatów, charakteryzujących zdolność konkurencyjną gospodarki [Misala 2013, s.15; Bieńkowski 1993, s. 32]. Zdolność konkurencyjna jest często nazywana konkurencyjnością czynnikową, ponieważ ocenia się ją na podstawie wielu czynników. Jest to zatem ujęcie konkurencyjności gospodarki narodowej od strony czynników sprawczych [Wziątek-Kubiak 2003, s. 9-13].

Narzędziem służącym do pomiaru konkurencyjności gospodarki narodowej jest wielowymiarowy Indeks Globalnej Konkurencyjności (Global Competitiveness Index - GCI), opracowany przez WEF. W konstrukcji GCI uwzględnia się zarówno mikro-, jak i makroekonomiczne aspekty narodowej konkurencyjności. Podstawowe znaczenie w jego budowie ma 12 czynników konkurencyjności nazywanych „filarami konkurencyjności”, które są zagregowane w trzy grupy subindeksów: A - czynniki podstawowe, $\mathrm{B}$ - czynniki poprawiające efektywność oraz C - czynniki innowacyjności i zaawansowania biznesu (rys. 1). Z kolei każdy z 12 filarów jest opisany przez wiele wskaźników cząstkowych, które wzajemnie uzupełniają się i oddziałują na siebie [World Economic Forum 2016, s. 38].

Poszczególne gospodarki są przyporządkowane do danego etapu rozwoju na podstawie wartości realnego PKB per capita. W zależności od poziomu rozwoju gospodarki każdej z rozpatrywanych grup czynników nadaje się różne wagi przy szacowaniu wskaźnika GCI. Na początku badanego okresu (2007 r.) przeważającą większość krajów EŚW (oprócz Estonii, Węgier i Słowacji) zaliczano do grupy krajów na drugim etapie rozwoju, na którym dużego znaczenia nabierają czynniki proefektywnościowe, m.in. efektywność rynku pracy. Wspomniane czynniki stanowiły 50\% wartości GCI. Tymczasem w ostatnim raporcie WEF z 2017 r. nastąpiło znaczne zróżnicowanie w ocenie poziomu rozwoju poszczególnych gospodarek. Na drugim etapie rozwoju pozostała tylko Bułgaria, trzy kraje zaś - Czechy, Estonia i Słowenia - przemieściły się do etapu trzeciego, sterowanego przez inwestycje. Sześć pozostałych krajów uplasowało się pomiędzy 2. i 3. etapem rozwoju gospodarczego. Pomimo tych zmian dla wszystkich krajów, oprócz Bułgarii, czynniki efektywnościowe nadal mają największe znaczenie i największą wagę przy szacowaniu GCI. 


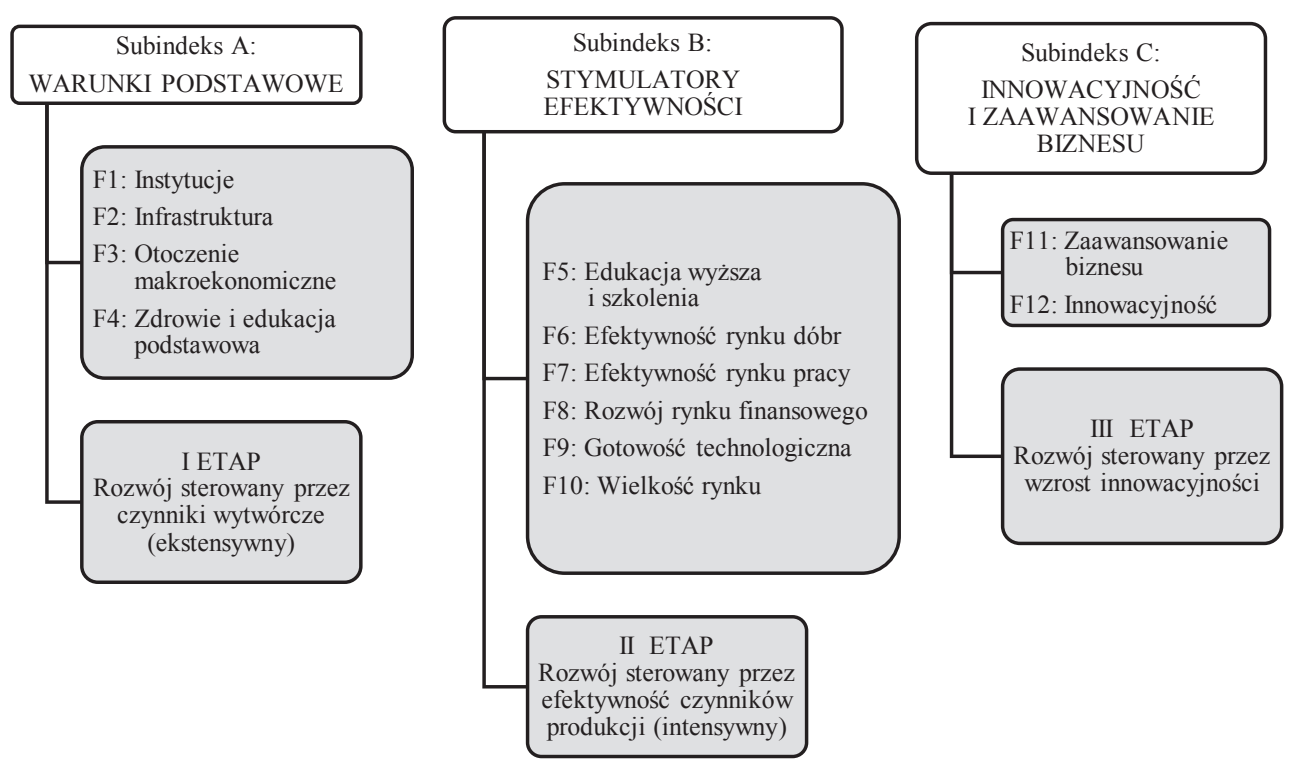

Rys. 1. Filary konkurencyjności i etapy rozwoju krajów

Źródło: opracowanie własne.

Należy dodać, że stosowana przez WEF metodologia jest ciągle doskonalona. Zaprezentowany model konkurencyjności gospodarki autorstwa World Economic Forum ma taką postać od 2007 r. Wcześniejsze edycje raportów w obrębie subindeksu B rozpatrywały tylko trzy filary konkurencyjności, a efektywność rynków - dóbr, pracy i finansowego - analizowano wspólnie. W kolejnych opracowaniach wszystkie trzy rynki doczekały się osobnych filarów [World Economic Forum 2007, s. 5]. $\mathrm{Z}$ uwagi na przedmiot analizy w dalszych rozważaniach uwaga zostanie skupiona na zmianach w obrębie subindeksu B i filara F7 - „Efektywność rynku pracy”.

Filar ten, zdaniem ekspertów WEF, odgrywa istotną rolę w kształtowaniu konkurencyjności międzynarodowej. Efektywność rynku pracy przejawia się przede wszystkim niskim bezrobociem i zdolnością do kreacji miejsc pracy, ale także wydajnością i elastycznością. Rynek pracy powinien być elastyczny, aby szybko i tanio przemieszczać pracowników z jednego sektora gospodarki do innego, elastyczność jest także konieczna przy ustalaniu płac. Czynniki te mają pozytywny wpływ na wydajność pracowników i atrakcyjność kraju dla talentów. Dodać należy, iż badania Światowego Forum Ekonomicznego są oparte na tzw. teorii efektywnościowej M. Portera [Porter 1998, s. 22]. W myśl tej teorii decydującą rolę w dochodzeniu do konkurencyjnej gospodarki odgrywa wydajność (efektywność produkcyjna i kapitałowa). Uznaje się, iż naturalnym celem każdego kraju jest wysoki poziom życia jego mieszkańców, a zdolność do zrealizowania tego celu zależy od produktywności 
zasobów. Wysoki poziom produktywności zapewni wzrost dochodów ludności i poziomu życia. Koncepcja konkurencyjności, oparta na wydajności i efektywności, może być używana w odniesieniu do badań na poziomie mikro i makro. Spojrzenie na konkurencyjność przez pryzmat wydajności i efektywności pozwala określić czynniki kształtujące wydajność firmy w sektorze, jak też politykę państwa w tym zakresie [Borowski 2015, s. 37].

\subsection{Zmiany konkurencyjności międzynarodowej krajów EŚW}

Analiza danych zamieszczonych w tabeli 3 pozwali określić zmiany, jakie dokonały się w zakresie konkurencyjności poszczególnych krajów EŚSW w ostatniej dekadzie, oraz ocenić wpływ czynników efektywnościowych na te zmiany.

Za najbardziej konkurencyjne w grupie badanych krajów można uznać gospodarki Estonii i Czech, które zajmują pierwsze dwie pozycje w obu rankingach. Najgorzej oceniono konkurencyjność Rumunii i Węgier, które w rankingu z 2017 r. uplasowały się na końcu zestawienia. W ciągu dziesięciu lat tylko cztery kraje (Polska, Czechy, Rumunia i Bułgaria) odnotowały wzrost relatywnej pozycji konkurencyjnej, najistotniejszy Bułgaria - 30 pozycji do góry i Polska - 12. Różnica między najlepszą pozycją w regionie a najniższą lokatą wynosiła w 2007 r. 52, w 2017 r. zaś - 39, co może świadczyć o postępującym procesie konwergencji gospodarczej w tej grupie krajów.

Tabela 3. Pozycja konkurencyjna krajów EŚW w rankingach WEF w latach 2007-2008 oraz 2017-2018

\begin{tabular}{|l|c|c|c|c|c|c|c|c|c|c|}
\hline \multicolumn{1}{|c|}{ Wyszczególnienie } & EE & LT & LV & PL & SI & SK & CZ & HU & RO & BG \\
\hline Pozycja wg GCI - 2007-2008 & 27 & 38 & 45 & 51 & 39 & 41 & 33 & 47 & 74 & 79 \\
\hline Pozycja wg GCI - 2017-2018 & 29 & 41 & 54 & 39 & 48 & 59 & 31 & 60 & 68 & 49 \\
\hline $\begin{array}{l}\text { Pozycja w obrębie subindeksu B } \\
\text { 2007-2008 }\end{array}$ & 27 & 41 & 42 & 43 & 38 & 34 & 30 & 40 & 62 & 72 \\
\hline $\begin{array}{l}\text { Pozycja w obrębie subindeksu B } \\
\text { 2017-2018 }\end{array}$ & 27 & 40 & 49 & 34 & 53 & 44 & 29 & 45 & 58 & 50 \\
\hline $\begin{array}{l}\text { Pozycja w obrębie filara F7- } \\
\text { 2007-2008 }\end{array}$ & 26 & 44 & 36 & 49 & 51 & 25 & 35 & 58 & 85 & 73 \\
\hline $\begin{array}{l}\text { Pozycja w obrębie filara F7- } \\
\text { 2017-2018 }\end{array}$ & 15 & 61 & 43 & 78 & 82 & 87 & 41 & 71 & 89 & 67 \\
\hline
\end{tabular}

* W zestawieniu WEF z okresu 2007-2008 ujęto 131 krajów, zaś w rankingu 2017-2018 - 137 krajów.

Źródło: [World Economic Forum 2007, s. 8, 12, 16; World Economic Forum 2017, s. 13, 326, 330].

Czynniki efektywnościowe ujęte w subindeksie B relatywnie najwyżej oceniono dla Estonii, najgorzej zaś dla Rumunii. Ogólnie można zauważyć, iż wyższa pozycja kraju w rankingu wg GCI odpowiada wyższej pozycji w rankingu wg subindeksu B. 
Wyjątek stanowi tu Słowenia, która w ogólnym rankingu konkurencyjności w 2007 r. zajmowała 5. pozycję, a wg czynników efektywnościowych - przedostatnią. Wynika to z pogorszenia jej pozycji w tym ostatnim zestawieniu o 15 miejsc w latach 2007-2017. Swoją drogą, eksperci WEF uznali, iż konkurencyjność gospodarki Słowenii uzależniona jest od innowacyjności w większej mierze niż pozostałych gospodarek (3. etap rozwoju). Niemniej jednak utrata konkurencyjności w zakresie efektywności grozi utratą pozycji konkurencyjnej w najbliższej przyszłości w stosunku do rywali. Odnotować należy duży postęp w tym zakresie Bułgarii i Polski, które znacznie polepszyły swoje notowania - odpowiednio o 22 i 9 pozycji. Biorąc pod uwagę wspomniany postęp tych krajów w zestawieniu wg GCI, można przypuszczać, iż poprawa efektywności wykorzystania czynników miała swój pozytywny wkład w poprawę ogólnej pozycji konkurencyjnej.

Efektywność rynku pracy (filar F7) oceniono bardzo różnie dla poszczególnych krajów EŚW. Wysoką pozycję (15. w rankingu światowym i 1. w regionie) zajmuje w tym zestawieniu Estonia. Dodać należy, iż jest to jeden z dwóch krajów (oprócz Bułgarii), które potrafiły poprawić swoją pozycję konkurencyjną w obrębie filara F7. Pozycję drugą wśród analizowanych krajów tradycyjnie zajmują Czechy, lecz miejsce tego kraju w porównaniu z Estonią jest znacznie niższe - 41. lokata wśród 132 sklasyfikowanych krajów. Na kolejnych pozycjach znalazły się dwa pozostałe kraje bałtyckie (Łotwa i Litwa) oraz Bułgaria. Pozostała piątka krajów uszeregowała się w kolejności: Węgry, Polska, Słowacja, Słowenia i Rumunia. Dodać należy, iż wszystkie te kraje znacznie pogorszyły swoje notowania w analizowanym okresie. Największego spadku efektywności rynku pracy doświadczyła Słowacja (62 pozycji w dół), znacznie mniejszy spadek odnotowały inne kraje - Słowenia (31), Polska (29) oraz Węgry (13).

Dla określenia roli rynku pracy w kształtowaniu konkurencyjności krajów EŚW ma sens dalsza dezagregacja zmiennych dla filara 7, opisujących najważniejsze elementy efektywnego rynku pracy. Wspomniany filar konkurencyjności jest opisywany przez dziesięć szczegółowo określonych zmiennych, które zostały przedstawione w tabeli 4.

Tabela 4. Szczegółowe czynniki konkurencyjności gospodarek państw EŚW w latach 2017-2018 na poziomie filara F7 (pozycja w rankingu)

\begin{tabular}{|l|c|c|c|c|c|c|c|c|c|c|}
\hline \multicolumn{1}{|c|}{ Wyszczególnienie } & EE & LT & LV & PL & SI & SK & CZ & HU & RO & BG \\
\hline 1 & 2 & 3 & 4 & 5 & 6 & 7 & 8 & 9 & 10 & 11 \\
\hline F7: Efektywność rynku pracy & 15 & 61 & 43 & 78 & 82 & 87 & 41 & 71 & 89 & 67 \\
\hline $\begin{array}{l}\text { 7.01 Współpraca w relacjach } \\
\text { pracodawca - pracownik }\end{array}$ & 25 & 58 & 47 & 79 & 62 & 75 & 34 & 77 & 99 & 111 \\
\hline $\begin{array}{l}\text { 7.02 Elastyczność w ustalaniu } \\
\text { płac }\end{array}$ & 2 & 13 & 4 & 24 & 107 & 60 & 10 & 68 & 33 & 53 \\
\hline $\begin{array}{l}\text { 7.03 Zasady zatrudniania } \\
\text { i zwalniania }\end{array}$ & 17 & 111 & 91 & 97 & 132 & 118 & 108 & 27 & 51 & 67 \\
\hline
\end{tabular}


Tabela 4, cd.

\begin{tabular}{|l|c|c|c|c|c|c|c|c|c|c|}
\hline \multicolumn{1}{|c|}{1} & 2 & 3 & \multicolumn{1}{c|}{4} & 5 & 6 & 7 & 8 & 9 & 10 & 11 \\
\hline $\mathbf{7 . 0 4}$ Koszty zwolnień & 47 & 103 & 49 & 80 & 39 & 80 & 86 & 53 & 8 & 20 \\
\hline $\begin{array}{l}\text { 7.05 Wpływ opodatkowania na } \\
\text { zachęty do podejmowania pracy }\end{array}$ & 59 & 121 & 117 & 128 & 135 & 131 & 113 & 88 & 126 & 96 \\
\hline $\mathbf{7 . 0 6}$ Wynagrodzenie i wydajność & 17 & 46 & 49 & 58 & 77 & 44 & 21 & 85 & 111 & 88 \\
\hline 7.07 Profesjonalne zarządzanie & 28 & 40 & 74 & 72 & 69 & 55 & 26 & 98 & 102 & 112 \\
\hline $\begin{array}{l}\text { 7.08 Zdolność kraju do } \\
\text { utrzymania talentów }\end{array}$ & 69 & 109 & 118 & 89 & 93 & 125 & 51 & 126 & 132 & 119 \\
\hline $\begin{array}{l}\text { 7.09 Zdolność kraju do } \\
\text { przyciągania talentów }\end{array}$ & 59 & 117 & 122 & 113 & 114 & 130 & 74 & 112 & 131 & 118 \\
\hline 7.10 Udział kobiet w rynku pracy & 29 & 18 & 22 & 63 & 27 & 67 & 64 & 62 & 81 & 34 \\
\hline
\end{tabular}

Źródło: [World Economic Forum 2017, s. 74-266].

Przegląd listy czynników pozwala zauważyć, iż w zakresie dwóch zmiennych Wpływ opodatkowania na zachęty do podejmowania pracy oraz Zdolność kraju do przyciągania talentów - wszystkie analizowane kraje (z wyjątkiem Estonii) notują słabe wyniki. Podobnie ma się sprawa z utrzymaniem talentów. Jakkolwiek lepiej radzą sobie z tym Estonia i Czechy, to dla pozostałych krajów ten obszar funkcjonowania rynku pracy stanowi istotną barierę $\mathrm{w}$ dochodzeniu do konkurencyjnej gospodarki. Tymczasem do czynników wspierających efektywność rynku pracy krajów EŚW można zaliczyć: Udział kobiet w rynku pracy (oprócz Rumunii) oraz Elastyczność w ustalaniu płac (z wyjątkiem Słowacji).

\section{Zakończenie}

Z przeprowadzonej analizy wynika, iż w ciągu ostatniej dekady konkurencyjność większości krajów EŚW (sześciu z dziesięciu) obniżyła się, na co wskazuje spadek pozycji w zestawieniu światowym. Najbardziej konkurencyjne w regionie są gospodarki Estonii i Czech, najmniej zaś - Rumunii. Niemal dla wszystkich krajów (oprócz Bułgarii) najistotniejszą rolę w kształtowaniu konkurencyjności (pozycji konkurencyjnej) odgrywają uwarunkowania proefektywnościowe, tj. kształtujące efektywność gospodarki narodowej. W obrębie tej grupy czynników istotnego znaczenia nabierają zmienne odpowiedzialne za efektywne funkcjonowanie rynku pracy. Czynnikami osłabiającymi konkurencyjność większości krajów EŚW są przede wszystkim czynniki charakteryzujące umiejętność przyciągania i utrzymania talentów oraz nieefektywny system podatkowy, zniechęcający do podejmowania pracy. Wzmacnia natomiast konkurencyjność tych krajów aktywność kobiet na rynku pracy oraz relatywnie elastyczny system płac. Niepokojące są odnotowane zmiany spadku efektywności rynków pracy niemal wszystkich krajów w regionie, z wyjątkiem Estonii i Bułgarii. 
W kontekście zmian, jakie zachodzą na współczesnym rynku europejskim i światowym, powstaje zagrożenie utratą konkurencyjności. Nieefektywnie funkcjonujący rynek pracy będzie istotnie obniżał skuteczność działania i przetrwania w konkurencyjnym otoczeniu. Można przypuszczać, iż stały spadek zasobów pracy $\mathrm{w}$ połączeniu z intensywnym procesem migracyjnym będzie zaostrzać problem niedoboru siły roboczej i hamować wzrost gospodarczy, a zatem i obniżać konkurencyjność gospodarek analizowanych krajów, w większym lub mniejszym stopniu.

\section{Literatura}

Bieńkowski W., 1993, Oddziaływanie rządu USA na rozwój zdolności konkurencyjnej gospodarki amerykańskiej w latach 1981-1998, Wydawnictwo SGH, Warszawa.

Borowski J., 2015, Koncepcje teoretyczne konkurencyjności międzynarodowej, Optimum. Studia Ekonomiczne, nr 4(76), Wydawnictwo Uniwersytetu w Białymstoku, s. 25-42.

Burnewicz J. (red.), 1993, Ekonomika transportu, Wydawnictwo Uniwersytetu Gdańskiego, Gdańsk.

Czajkowski Z., Gomułka M., 2010, Międzynarodowa konkurencyjność gospodarki: metodologie pomiaru, [w:] Konkurencyjność Polski na tle zmian gospodarczych w krajach OECD, red. W. Bieńkowski, M.A. Weresa, A.J. Radło, Wydawnictwo SGH, Warszawa.

Eurostat 2017, http://ec.europa.eu/eurostat/data/database (12.05.2017).

Gorynia M., Jankowska B., 2008, Klastry a międzynarodowa konkurencyjność i internacjonalizacja przedsiębiorstwa, Difin, Warszawa.

Gorynia M., Łaźniewska E. (red.), 2009, Kompendium wiedzy o konkurencyjności, PWN, Warszawa.

Misala J., 2013, Teoretyczne podstawy rozwoju dtugookresowych przewag konkurencyjnych w handlu międzynarodowym, [w:] Kapitat ludzki i innowacyjność jako czynniki dtugookresowych przewag konkurencyjnych $w$ handlu międzynarodowym. Wnioski dla Polski, red. M.A. Weresa, Wydawnictwo SGH, Warszawa.

Porter M.E., 1998, Strategia konkurencji. Metody analizy sektorów i konkurentów, PWE, Warszawa.

UN, 2017, World Population Prospects: The 2017 Revision, United Nations, https://esa.un.org/unpd/ wpp/DataQuery/ (2.01.2018).

World Economic Forum, 2007, The Global Competitiveness Report 2006-2007, Geneva.

World Economic Forum, 2016, The Global Competitiveness Report 2016-2017, Geneva.

Wziątek-Kubiak A., 2003, Konkurencyjność polskiego przemysłu, Bellona, Warszawa. 